\title{
The Effect of Using Problem- Based Learning upon Students' Emotions towards Learning and Levels of Communication Skills in Three Different Disciplines
}

\section{Malek Jdaitawi}

Self-Development Department, Deanship of Preparatory Year and Supporting Studies, Imam Abdulrahman Bin Faisal University

\section{Abstract}

In the past few years, teaching staff have been motivated to engage students in different forms of communication. This quasi-experiment study presents the implementation of the problem-based learning (PBL) approach in the first-year classroom environment with the goal to enhance students' communication skills and promote their positive emotions toward learning. The study was carried out involving students studying in health, engineering and science fields. They were categorized into two groups, namely experimental (90 students) and control group (90 students). The study period lasted 4 weeks, during which the module was taught to 180 first-year students in both groups. The findings revealed the learning approach significantly affected the students' communication skills and their emotions concerning learning. Finally, conclusions were drawn from the study.

Key words: emotions towards learning; engineering field; health field; science field; university setting.

\section{Introduction}

The past decades witnessed researchers' attempting to identify the determinants of successful learning among students at all levels. In fact, the majority of studies in this context have related successful students to the psychological, environmental, and social factors, along with learning and teaching approaches (e.g. Nalova \& Shalanyuy, 2017; Stentoft, 2017; Erdogan \& Senemogly, 2017; Vujicic et al. 2018). More recently, educators 
have come up with several teaching strategies geared towards transforming the curriculum content and mitigating the gap between classroom and world requirements (Beausaert et al. 2013). Additionally, instructional practices are crucial to the teaching/learning processes - such practices are described as the teachers' activities in the classroom, involving teaching methods, assessment, and management. In this regard, researchers have related instructional practices to successful student achievement in the academia; and also their communication skills, ability to be insightful and critical in their way of thinking (Nalova \& Shalanyuy, 2017; Seidel \& Shavelson, 2007; Mandeville et al., 2017). Hence, it can be stated that the instructional process, materials and assessment are all significant in improving the student learning outcomes and their acquisition of higher-order thinking skills.

In higher education institutions, there are still issues in learning approaches, especially for the first-year students. In the realm of learning, problem-based learning (PBL) has been extensively accepted as a medium of instruction in different disciplines (Chung et al., 2016; Hung et al., 2008). In fact, it is one of the top integrated and current teaching methods brought into light in literature, owing to its suitability and effectiveness in enhancing the students' personal, emotional, social and cognitive skills. PBL brings about the effective collaboration, higher order thinking, problem solving, social skills and academic achievement among students (El-Shaer \& Gaber, 2014; Argaw et al., 2017; Santon et al., 2017). In other words, it is crucial to utilize PBL and other effective learning strategies promoting student attitudes towards learning in higher education institutions. Consequently, PBL has been largely implemented in several educational disciplines owing to its potentials for boosting students' learning capabilities (Hung et al., 2008). The majority of studies pointed to the positive PBL contribution to learning/ teaching processes and, more importantly, to students 'learning skills, as evidenced in literature (e.g. Stentoft, 2017; Argaw et al., 2017; Webb \& Moallem, 2016). According to Hamalainen (2004), PBL works towards enhancing communication, interaction, cooperation and cognition of students, all of which is important for their problem solving and critical thinking skills. In sum, PBL is considered invaluable to enhancing cognitive levels of students, and ultimately their successful academic achievement. However, regardless of the aforementioned studies and their findings, research on students' successful achievement in light of the PBL's effects on learning and teaching as well as on student abilities are still scarce (Yew \& Goh, 2016; Stentoft, 2017). This is reflected in limited consideration given to teaching this module in the environment of university education. Moreover, researches on the issue that delves into the effect of PBL on student communication skills and emotions towards learning are almost non-existent. Hence, due to the paucity of required research in literature, this study tries to offer a potential practical solution to the issue by developing a module that could enhance communication skills of university students and boost their positive emotions towards learning. This study investigates communication units at different student levels in Saudi Arabia (preparatory year students). 


\section{Developing Students' Communication Skills through PBL}

Universities have a general need to inculcate personal and transferable skills in students in order to prepare them and help them choose the future career; in health, engineering or science (Mitchell et al., 2010). This is because, despite the need for students to acquire a robust personal, social and cognitive skills, majority of them are still in lack of these skills. Studies are therefore drawn towards examining the role of communication and social interaction in the realm of teaching and learning, particularly among first-year classrooms at universities (Awang \& Daud, 2015). In addition, there are different communication skills (verbal, non-verbal, and written skills) that enable the engagement of students with their classmates and teachers in developing and improving their subject knowledge. Hence, PBL has reached quite a high level of popularity owing to its effective teaching and learning methods in different higher education disciplines (Chung et al., 2016). More specifically, PBL refers to an approach that assists students' development of self-directed learning skills, originating from the premise that learning is a process wherein which the learner is actively involved in developing new knowledge based on the current.

PBL enables students to make use of the triggers from a problem case or situation for establishing their learning focus. After this, they independently go through selfdirected learning, prior to discussing with the group and refining their newly acquired knowledge (Awang \& Daud, 2015). Moreover, PBL is not only confined to problem solving, but it also covers suitable problems to maximize students' cognition and reasoning. In relation to this, students' group learning boosts knowledge learning as well as other attributes (communication skills, teamwork, problem solving, independent learning responsibility, sharing information, and respect for peers and instructors) (Mitchell et al., 2010; Major, 2001). Furthermore, PBL enables students to obtain and hone their practical skills, receive feedback from peers and professors, acquire guidance and support from them and develop collaboration and integration skills in the group. It works towards enhancing their communication and team-work skills as well as their problem-solving skills, creative thinking and knowledge acquisition skills (Awang \& Daud, 2015; Mitchell et al., 2010; Selcuk et al., 2010; Tan, 2003). Students acquire new information via self-directed learning, where they are responsible for gathering information from different learning sources. They collaborate, compare and review, and discuss what they have learned among each other.

Studies showed that PBL is effective in enhancing such skills among university students although such studies are still few and far between. To begin with, Santon et al. (2017) examined the effect of transfer of problem-based learning skills to clinical practice among 19 graduate students. The results reported notable improvement in students' thinking skills, effective communication with colleagues and patients, as well as improving their clinical skills. Mandeville et al. (2017) studied the effect of problembased learning on oral communication competency among 80 undergraduate students in kinesiology courses. The results reported that student communication competency 
has improved over the study period. To illustrate the effectiveness of the PBL approach, Chung et al. (2016) examined the influence of the PBL strategy on enhancing students learning outcomes regarding industrial-oriented competences. The students in the experimental group were taught through the PBL strategy, and the control group by traditional strategy. The result of the study revealed that the instructional activity became more interesting after applying PBL and students learning outcomes were enhanced. Awang and Daud (2015) examined the effect of PBL as a learning method used to enhance student communication skills. Their quasi-experimental study involved 60 engineering students divided into two groups, namely, experimental and control group, in an examination spanning 8 weeks. The results of the mentioned study evidenced the effect of PBL on the students' communication skills and learning approach. In his mix method study, Abdur-Rohim (2014) examined the effect of the problem-based strategy on improving speaking skills among 46 students. Abdur-Rohim (2014) used four instruments to assess students' skills. The results revealed mean values of students speaking skills improved in the post-test, compared with the mean scores in the pretest. Along a similar line of study, Mitchell et al. (2010) found students' motivation and perception increased following the PBL module's implementation in their study that evaluated the communication system course with the use of PBL. Also, Tarmizi et al. (2010) carried out a quasi-experimental study involving 24 foundation year students in their attempt to investigate PBL and its ability to enhance students' mathematics learning, competency, thinking and communication. They found no significant difference between the PBL and control group in the context of mathematics. However, there was a significant difference between the PBL and control group in terms of engagement and mental efforts. Therefore, PBL is effective in enhancing students' communication skills.

\section{Promoting Student Positive Emotions towards Learning through PBL}

The study's focus on the current education of preparatory students aims towards assisting them in establishing future survival. This is aligned with the heightened interest of the curriculum reforms which focus on developing student competencies, academic skills and knowledge of the subject material. In recent years, emphasis has been placed on the workplace and social skills. In relation to this, teaching methods and socio-emotional skills have significant influence, in comparison to conventional intelligence, on various types of career, education and personal achievements (Mitchell et al., 2010; Pekrun et al., 2005). Regardless of the evidence of PBL's importance in prior literature (Kanet \& Barut, 2003; Maria \& Anthony, 2012; Strobel \& Barneveld, 2009), research on understanding its influence on motivation is still limited (Fukuzawa et al., 2017). Savery (2006) also contributed to the PBL literature by describing it as an instructional approach introducing learners to research, theory integration and practical uses (knowledge and skills application) for solving problems (p.9). Although in recent years several studies have focused on the effect of PBL on students" learning outcomes such as achievement, satisfaction, perceptions, thinking skills, communication and selfregulation, a study dedicated to promoting student emotions about learning through 
problem-based learning strategy does not exist. Nevertheless, the positive effect of this approach on student emotions has been noted and reported in an indirect manner. For example, Argau et al. (2017) investigated the effect of problem-based learning on students' motivation and problem solving skills in physics. A quasi-experimental study was conducted on 81 students. The result revealed no significant difference in the effect on the study variable between experimental and control groups. Erdogan and Senemoglu (2017) examined the effectiveness of the problem-based learning on students' academic achievement and self-regulation. Fifty-seven students participated in the study of language testing and evaluation course at the Middle East Technical University in Turkey. The results of the study revealed that problem-based learning was effective for students' knowledge and achievement, but did not affect students' self-regulation. Ashley and Mahnaz (2016) examined the effect of the problembased learning strategy in promoting feedback and feed-forward in online learning environment among eleven undergraduate students. The result of their mix method study showed that the PBL strategy supported student achievement, and the strategy motivated students and provided them with reference for areas of improvement. ElShaer and Gaber (2014) examined the impact of problem based learning approach on critical thinking and other variables among 200 nursing students at Mansoura University. The result indicated students in the PBL group improved their critical thinking skills over the intervention period. Also, Maria and Anthony (2012) examined the impact of problem based learning on students' attitude towards science, as well as problem solving and sense of community in the classroom among 48 students. However, the results of the questionnaire and student journal, as well as teacher observation, showed that students scored higher in problem solving skills, and had a more positive attitude towards science and the learning environment. In Halverson's (2003) study, PBL was noted to mitigate negative emotions among students, including their uncertainty, stress and helplessness, as it provides concrete and realistic activities. Similarly, Struthers et al. (2000) reported that college students engaging in problem-focused activities had a greater tendency to be motivated to perform better, compared to their emotion-focused counterparts. In addition, PBL positively affects student perceptions concerning their ability to make use of emotion-centered coping. Furthermore, the management process of the student-focused approach of learning, along with realistic problems, enables them to enhance their abilities of managing their negative emotional responses related to high-level stress. Above all, the PBL seems to boost students' motivation in that students tend to feel more involved in actual situations and not merely in theories (Borhan, 2012). In conclusion, PBL can be related to consequential positive and negative results.

\section{The Effect of Study Fields on Using the PBL}

The primary aim of education is to assist in better learning and aquisition of higher order thinking skills that are invaluable for students' future careers and lives. Hence, the PBL method has a key role in realizing enriching and retentive learning motivation and problem-solving, creative thinking and critical thinking (Fukuzawa et al., 2017; El- 
Shaer \& Gaber, 2014). The PBL approach has been likened to an appropriate approach that enables the association of students' prior knowledge with newly acquired while working in teams on solving actual problems (Fukuzawa et al., 2017). The majority of the studies dedicated to the PBL evidenced its positive effects on students' problemsolving skills (Argau et al., 2017), communication, teamwork and engagement, as well as overall cognitive skills (for problem solving and creative thinking) (Stentoft, 2017; ElShaer \& Gaber, 2014). It also encourages them to interact in their learning surroundings (Sungur \& Tekkaya, 2006). It is therefore concluded that the PBL method will positively impact different aspects of students' learning in terms of health education, as evidenced by Raupach and Digerleri (2010) and Lin and Digerleri (2010), engineering education, as evidenced by Awang and Ramly (2008), as well as in science education, as evidenced by Celik et al. (2011). The approach can be used in teaching small groups that integrate knowledge acquisition and development of generic skills, attitudes and emotions. This can be exemplified by the presentation of the clinical material to stimulate learning among students and to let them understand the underlying scientific knowledge and principles of clinical practices. In the context of science, it was noted that students search for opportunities to practice their courses and take part in discussing their knowledge in groups in order to make up for their weaknesses through information exchange. Lastly, the students' practical skills in engineering are enhanced, particularly among novice students. Although the PBL method showed many advantages compared to other learning methods, few studies focused on the effect of PBL in different disciplines. Therefore, this study will add to literature by examining different effects of PBL on students from three different disciplines.

In literature about the PBL module, its nature and effects on communication skills and student learning emotions, authors including Hartman et al. (2013), Awang and Daud (2015), and Tarmizi et al. (2010) call for carrying out further studies. This is particularly true for studies focused on the effect of PBL in the university environment of first-year students, stressing the need to extend literature by investigating the same technique. Stentoft (2017) conducted a study aimed at examining the intentions and principles of interdisciplinary learning and problem-based learning. The result of the study revealed problem-based learning is a potentially compelling pedagogical practice conducive for student learning across disciplines. Fukuzawa et al. (2017) examined the effect of student motivation in response to problem-based learning among 49 students from different courses at the university level. The result of the study showed students' motivation towards problem-based learning was improved at the end of the study. In their experimental study, Thabet et al. (2017) examined the effect of problem-based learning on nursing students' decision making skills where eighty-four nursing students were involved in the study and divided into two, PBL and control, groups. The results revealed that students in the PBL group increased their decision making and styles compared to students in the control group. Faisal et al. (2016), for example, researched the effectiveness of problem-based learning with 146 medical students at Rehman Medical College in Bakistan. Mean scores of 
academic performance for students in the PBL group showed higher than those of their counterparts in the control group. However, Faisal et al. (2016) reported the PBL strategy was an effective way of teaching. Augusthy (2016) compared the classroom based on PBL with a lecture-based classroom among medical college students. As a result; although students taught in the PBL and lectured-based learning groups both showed better outcomes in recall, analytical, critical thinking, and problem-solving, the PBL group was found to be more effective in satisfaction and motivation than students in the lectured-based learning group. In their quasi-experimental design study, Kadir et al. (2016) examined the comparative effect of PBL on problem solving skills between the experimental and control group. Students in the experimental group were given four problems and were assessed accordingly, while students in the control group were taught by the traditional method. Results of the study revealed students in the experimental group showed better problem solving skills than the ones from the control group. Boer et al. (2014) conducted a study to examine the effect of the problem-based learning approach on the statistics course among engineering students. They reported students and professors showed great satisfaction about the application of PBL in their learning/teaching process. Furthermore, the results indicated that $89 \%$ of the students benefited from the activity offered by PBL. Hartman et al. (2013) investigated the effect of problem based learning in introductory business courses among business students. A pre/post-test study design was used to compare the benefits of PBL on students' tolerance of ambiguity, problem-focused coping and emotionfocused coping. However, the results reported that PBL positively affects students' perceptions of their ability to use emotion-focused coping, but no effect on students' problem-focused coping was found, whereas the effect on the students' tolerance for ambiguity was negative. Celik et al. (2011) examined the PBL's effect as a learning method on students' success in the physics course. Their quasi-experimental study involved 44 students who were divided into two groups, namely, 20 students in the experimental and 24 students in the control group. The results of the study evidenced higher student achievement in physics in the PBL group than in the control group who learnt in a traditional lecture approach.

To sum up, the majority of studies examining effects of the PBL strategy to date have focused on medicine, engineering, science, physics and arts independently, not together, or made a comparison between them in one study. Therefore, this study primarily contributes to literature by examining the influence of the PBL strategy on the first-year university students' communication skills and emotions about learning. This would furnish an understanding of the related significance of the concepts for successful academic achievement of students. Accordingly, three primary research questions are developed: Are there any significant differences between the PBL group and the control group at the level of communication skills; Are there any significant differences between the PBL group and the control group at the level of emotions related to learning; Does the factor of the study field contribute to the effect of PBL on students' communication skills and emotions towards learning? These three 
questions led to formulation of the following hypotheses: PBL has an effect on students' communication level; PBL has an effect on students' emotions towards learning; and lastly, the effect of PBL will be different in different study fields.

\section{Methodology}

\section{Research Design}

This study adopted a quasi-experimental design and a quantitative survey method. The case study was examined with the use of the survey method, and the researcher's observations described. (Babbie \& Mouton, 2001). According to Sekaran (2003), the survey method is suitable in gathering in-depth data on the attitudes and beliefs of respondents, particularly due to large sample size.

\section{Sample and Procedures}

The study sample consists of preparatory college students at the Imam Abdulrahman Bin Faisal University in Eastern Saudi Arabia. Preparatory year college was suitable for this research as it comprises students from various college fields such as health, engineering, and science, as well as the fact it was near to the researcher who conducted the experiment required by this study. Furthermore, the preparatory year college was recruited to present students with a broad range of ability levels, but of the same social, cultural and economic status. The participants in this study were all Saudian from the Eastern region in Saudi Arabia, with same cultural and social characteristics. In terms of the economic factor, the university is located in a highly developed economic area and receives support from the government, so all students got monthly allowance which covers their personal, social and academic needs. Furthermore, previous studies supported the claim that neiter cultural nor economic factors affected the success of PBL in university settings, as PBL helps student to collaborate with each other (Krishnan et al., 2011). Therefore, according to the researcher and his colleagues' opinions, these factors should not be considered as affecting the study results and were disregard from the study objectives.

A sample of one hundred eighty students at three levels of preparatory year were involved in responding to the questionnaires. Purposive sampling was used, based on the inclination to participate of students at health, engineering and science faculties (2017-2018). Language competency plays a key role in choosing these fields of study, as English is the common teaching language. A sample of 180 students was chosen and randomly categorized into the PBL group (90 students) and the control group (90 students), with 30 students from the health faculty, 30 from engineering faculty, and the remaining 30 from the science faculty. This distribution corresponds with the group sizing in the educational system of Saudi Arabia. Students from the three fields (health, engineering and science) were involved in this research attempt in which we tried not to disregard any of them, as well as control the effect of the study field on the results. Furthermore, the students were from three preparatory year college fields, 
as the college is the fundamental year for all university students. Furthermore, the students were selected in the same way from the classes learning the same subjects up to the time of the experiment. All students majoring in health, engineering and science took the same subjects at the same time for credit required for graduation at the university. The students were 19 years of age in average, and they were in their second semester of study.

Experimental and control groups were exposed to 4 weeks of implementing PBL and the traditional approach, and they were given a pretest prior to studying and a posttest after completing the four study weeks. Students in the PBL group were introduced to the procedure and given activity in every single class in order to save time. The units of instruction in this study were limited to four topics of the self-development course syllabus. Therefore, few PBL steps and student activities were combined in the same course. The teaching procedures for the control group remained the same, traditional method where students were taught by lecturing, i.e. giving thematical content, concepts and principles, and acted as passive learners. The experimental group was taught through the application of PBL. Several steps and processes were adapted and used in this study such as problem orientation, implementation method and assessment strategy. These three procedures were implemented in every single course in order to achieve the syllabus outcomes. During four weeks of implementing the PBL approach, students were scheduled to solve four problems related to four given topics. Implementing PBL in this study was realised by using Blackboard Learning System through uploading learning materials such as power-point presentations, reflective journals, videos, and pictures of the groups. At the beginning of every PBL course, students were divided into groups and appointed a different leader for a different problem, engaged in active learning and discussed the same problem presented through a video related to the four given topics. After that, students gained information about the topics through life situations. They were given additional images representing the problem as well as asked to answer questions related to the problem. During the time of the course, students discussed the topic and presented their feedback, their activities and related issues raised by the lecturer. The lecturer anticipated the section that needed most discussion and explanation in the course. Finally, students applied the acquired knowledge through the implemented learning strategy, gave feedback and made assessments. In adition, the lecturer provided the students with extra materials to facilitate their understanding and knowledge about the topic, and gave assignments connected with the topic.

\section{Outcome Measurements}

Communication skills were measured through using the communication skills survey developed by Chung et al. (2016). Eighteen key features of communication skills were developed and assessed on the 5-point Likert scale ranged from 1 (strongly disagree) to 5 (strongly agree). The items included: I understand how the other party is feeling 
by reading their facial expression; I pay attention to what others are saying, as people could have different views; I put myself in other person's shoes while leading the conversation. This scale was chosen owing to its high internal reliability and significant validity, and it has been used previously (Chung et al., 2016) with the obtained alpha coefficient of 0.83 . Emotions towards learning, the measurement proposed by Pekrun et al. (2005), were used to measure the construct of emotions towards learning. It comprises 8 items focused on gauging the students' emotions in their classes, where respondents were requested to respond to items along a five-point Likert scale that ranged from 1 (strongly disagree) to 5 (strongly agree). The items included: I look forward to studying; I feel optimistic about making good progress in studying; I have great hope that my abilities will be sufficient. The items focused on the emotions experienced by students in class. The Cronbach's alpha coefficient of the items was 0.85 , indicating satisfactory internal consistency.

\section{Analysis}

The Cronbach's reliability coefficient for the communication skills survey was 0.801 , and for the learning related emotions 0.807 . Since the results exceeded the general standard value of 0.80 , the internal consistencies of measures were judged to be acceptable. Tables 1 and 2 show descriptive statistics tests such as mean standard deviation for the pretest and the post-test.

Table 1

Means and standard deviations of the communication skills measure with different groups and test time

\begin{tabular}{lccccc}
\hline \multirow{2}{*}{ Study Group } & \multicolumn{3}{c}{ Communication Pretest } & \multicolumn{2}{c}{ Communication Post-test } \\
\cline { 2 - 6 } & $\mathrm{n}$ & $\mathrm{M}$ & $\mathrm{SD}$ & $\mathrm{M}$ & $\mathrm{SD}$ \\
\hline Problem Based Learning grup & 90 & 2.79 & .332 & 3.30 & .468 \\
Control Group & 90 & 3.02 & .339 & 3.15 & .453 \\
Overall Pretest & 180 & 2.91 & .353 & 3.22 & .465 \\
\hline
\end{tabular}

Note. $\mathrm{SD}=$ Standard Deviation

Table 2

Means and standard deviations of the measure of learning-related emotions with different groups and test time

\begin{tabular}{lccccc}
\hline \multirow{2}{*}{ Study Group } & \multicolumn{3}{c}{$\begin{array}{c}\text { Learning-Related } \\
\text { Emotions Pretest }\end{array}$} & \multicolumn{2}{c}{$\begin{array}{c}\text { Learning-Related } \\
\text { Emotions Post-test }\end{array}$} \\
\cline { 2 - 6 } & $\mathrm{n}$ & $\mathrm{M}$ & $\mathrm{SD}$ & $\mathrm{M}$ & $\mathrm{SD}$ \\
\hline Problem Based Learning grup & 90 & 3.02 & .585 & 3.75 & .629 \\
Control Group & 90 & 3.44 & .523 & 3.51 & .748 \\
Overall Pretest & 180 & 3.22 & .465 & 3.63 & .700 \\
\hline
\end{tabular}

Note. SD = Standard Deviation

On the basis of the results from the initial analysis, statistically significant mean differences were found between the PBL and control groups on the pre-test data of dependent variables. The mean difference in the pretest score of the communication $(\mathrm{PBL}$ group mean $=2.79, \mathrm{SD}=.332$; control group mean $=3.02, \mathrm{SD}=.339)$ was 
significant $(\mathrm{F}=8.409, \mathrm{p}=.006<.05)$. Based on these results, the analysis of the variable types (dependent and independent) was conducted employing the ANCOVA (analysis of covariance). The ANCOVA enabled the study of the main independent variables (experimental and control groups), with and without the covariate. Furthermore, the ANCOVA controls the factors that would affect the result of the study. To closely examine the statistical significance of the mean differences for the variables, ANCOVA was performed using the post-test scores as the dependent variable, after setting the pretest score as a covariate. Controlling the pretest score as the covariate is known to increase statistical power by reducing the unexpected variance in the post-test score. More specifically, Table 3 tabulates the results obtained from the ANCOVA. The result in Table 3 shows evidence of a statistically significant mean difference between the two groups of students (PBL and control group) in terms of communication skills. The table indicates the PBL group projected higher communication skills in comparison to their control group counterpart $(\mathrm{F}=5.279, \mathrm{P}=.023<.05)$. This means that the PBL designed in the present study was significantly effective in improving students' communication mean scores in the PBL group $(\mathrm{M}=3.30, \mathrm{SD}=.468)$, as compared with the control group $(\mathrm{M}=3.15, \mathrm{SD}=.453)$. The mean difference in the pretest score of the learning related emotions ( $\mathrm{PBL}$ group mean $=2.75, \mathrm{SD}=.435$; control group mean $=2.95, \mathrm{SD}=.488)$ was significant $(\mathrm{F}=19.915, \mathrm{p}=.000<.05)$. Based on the results, the analysis of the variable types (dependent and independent) was conducted employing the ANCOVA (analysis of covariance).

The results in Table 4 showed a statistically significant mean difference, also noted in terms of emotions towards learning, where the PBL group obtained higher positive emotions $(\mathrm{M}=3.75, \mathrm{SD}=.629)$ compared to their control group counterparts $(\mathrm{M}=$ $3.51, \mathrm{SD}=.748)$. However, the result of the ANCOVA $(\mathrm{F}=5.552, \mathrm{p}=.020<.05)$ was significant. This means that the PBL designed in the present study was significantly effective in promoting positive emotions towards learning in the PBL group, as compared with the control group. With regards to comparing dependent variables based on the students' study major, the MANOVA was conducted to examine whether significant mean differences exist between the three study majors on the dependent variables, study communication and learning related emotions, as shown in Table 5. Although the result of descriptive statistics showed that students from the health field attained higher mean $(\mathrm{M}=3.364, \mathrm{SD}=.503)$ scores of communication skills in comparison to those in the other fields, engineering $(\mathrm{M}=3.303, \mathrm{SD}=.435)$ and science $(\mathrm{M}=$ $3.242, \mathrm{SD}=.472)$, the obtained result of the MANOVA was $(\mathrm{F}=1.470, \mathrm{p}=.236>.05)$ insignificant. Along the same line of study, health students also showed higher level of positive emotions towards learning $(\mathrm{M}=3.916, \mathrm{SD}=.621)$ compared to students in the other remaining faculties, engineering $(\mathrm{M}=3.708, \mathrm{SD}=.587)$ and science $(\mathrm{M}=$ $3.654, \mathrm{SD}=.666)$, the obtained MANOVA was $(\mathrm{F}=.504, \mathrm{p}=.606>.05)$. This means that the PBL designed in the present study was significantly effective in improving the mean scores of students' communication and in promoting positive emotions in the health field, as compared with the other fields of study. 
Jdaitawi: The Effect of Using Problem-Based Learning upon Students' Emotions towards Learning and Levels ...

Table 3

ANCOVA for between-subject effects on the post-test of communication skills with different groups

\begin{tabular}{lrcccc}
\hline Source & \multicolumn{1}{c}{ SS } & df & MS & F & $\mathrm{p}$ \\
\hline Model & 1.414 & 2 & .707 & 3.342 & .038 \\
Pre-test & .418 & 1 & .418 & 1.975 & .162 \\
Group & 1.116 & 1 & 1.116 & 5.279 & $.023^{*}$ \\
Error & 37.432 & 177 & .211 & & \\
Total & 1915.978 & 180 & & & \\
\hline
\end{tabular}

Note. $\mathrm{SS}=$ Sum of Square, $\mathrm{df}=$ Degree of Freedom, MS = Mean Square, $\mathrm{F}=\mathrm{F}$ Value, $\mathrm{p}^{*}=$ Confidence Level $<.05$.

Table 4

ANCOVA for between-subject effects on the Post-Test of learning related emotions with different groups

\begin{tabular}{lrrrrl}
\hline Source & \multicolumn{1}{c}{ SS } & df & \multicolumn{1}{c}{ MS } & \multicolumn{1}{c}{$\mathrm{F}$} & $\mathrm{p}$ \\
\hline Model & 2.671 & 2 & 1.335 & 2.777 & .065 \\
Pre-test & .012 & 1 & .012 & .025 & .874 \\
Group & 2.669 & 1 & 2.669 & 5.552 & .020 \\
Total & 2470.328 & 180 & & & \\
\hline
\end{tabular}

Note. $\mathrm{SS}=$ Sum of Square, $\mathrm{df}=$ Degree of Freedom, MS = Mean Square, $\mathrm{F}=\mathrm{FValue}, \mathrm{p}^{*}=$ Confidence Level $<.05$.

Table 5

MANOVA for between-subject effects on the post-test of communication skills with different study field

\begin{tabular}{llrrrrc}
\hline Source & Dependent Variable & \multicolumn{1}{c}{ SS } & df & MS & F & p \\
\hline Correct Model & Communication Skills & .224 & 2 & .112 & .504 & .606 \\
& Learning Emotions & 1.152 & 2 & .576 & 1.470 & .236 \\
\multirow{3}{*}{ Study Field } & Communication Skills & .224 & 2 & .112 & .504 & .606 \\
& Learning Emotions & 1.152 & 2 & .576 & 1.470 & .236 \\
\multirow{3}{*}{ Error } & Communication Skills & 19.351 & 87 & .222 & & \\
& Learning Emotions & 34.105 & 87 & .392 & & \\
\multirow{2}{*}{ Total } & Communication Skills & 1001.8 & 90 & & & \\
& Learning Emotions & 1307.4 & 90 & & & \\
\hline
\end{tabular}

Note. $\mathrm{SS}=$ Sum of Square, $\mathrm{df}=$ Degree of Freedom, $\mathrm{MS}=$ Mean Square, $\mathrm{F}=\mathrm{F}$ Value, $\mathrm{p}^{*}=$ Confidence Level $<.05$.

\section{Discussion}

The first question is dedicated to determining the differences between the PBL and control groups in terms of communication skills. The obtained results pinpointed the existence of significant mean differences and indicated the PBL group got higher communication skills scores compared to their control group counterparts. This result may be attributed to the fact that students in the PBL group received higher support from their environment and experienced higher competition that boosted their communication level. The result may also be attributed to the comfort felt by the students in their classroom environment and their sense of belonging. Additionally, 
students were requested to work in teams to solve the activities and this assisted in coping with the demands and pressures in class. Furthermore, a different learning strategy was offered based on PBL, different from the lecturing strategy used by lecturers, i.e. learning through a variety of activities such as involving small group dynamics and learning through real life situations related to the topics and thus enhancing students' communication skills. Furthermore, learning through the PBL approach may encourage students to interchange their knowledge and facilitates their adaptation to new learning styles, which helps them in evaluation and refinement of their learning by providing a collaborative feedback through mutual interaction (Fung, 2013), which assists the students in overcoming communication difficulties. Moreover, the surveyed students were in their second semester of study and thus it was expected they have had time to enhance their communication skills. This result is aligned with prior findings of Santon et al. (2017), Awang and Daud (2015), Tarmizi et al. (2010), as well as Nur-Izzati et al. (2010), with the latter supporting the positive influence of the PBL strategy on the skills of students. On the whole, the results showed that the PBL, as an instructional approach, succeeded in enhancing students' communication skills.

The second question aimed to determine the existence of the mean differences between the PBL and control groups in terms of their emotions towards learning. The results of descriptive analysis indicated significant mean differences, in that students from the PBL group achieved higher scores compared to their peers from the control group, namely, the former showed higher levels of positive emotions towards learning. This result may be related to the fact that the PBL module is suited to increase students positive emotions about learning. This result may also relate to the fact that students from the PBL group received high support from their environment, which motivated and enhanced positive emotions towards learning. However, the PBL strategy promoted learning and changing the learning attitude. It may also be related to the fact that the PBL group worked in teams to solve activities, and this assisted their emotional and relationship management with peers - these students had a higher tendency to be confident, which may have also contributed to their positive learning emotions. The PBL instructional method also facilitated the PBL group's interaction with peers and their interaction with the surroundings. Higher level of communication shown by these students may also have had a hand in their higher positive emotions towards learning, compared to their control group peers. This result is aligned with the one reported by Hartman et al. (2014). In their study (ibid.), the authors supported the positive influence of PBL on the perceptions among students about their ability to make use of emotion-centered coping, and in managing their student-centered learning and actual problem solving. This type of problem-solving enhances students' abilities towards managing negative emotional reactions related with pressure and stress. Meanwhile, Lee and Kim (2005) indicated a strong motivational effect of the PBL.

Lastly, the third question aims to determine the existence of significant mean differences between the study variables on the basis of the study fields. Results indicated 
that, although health students obtained higher scores compared to the two remaining groups in their communication scales and learning-related emotions, the differences were insignificant. This may be due to the fact learning equity among diverse study fields is a mission that is advocated by the university and its staff. Added to this, the college staff is particularly helpful in facilitating knowledge acquisitions. Literature supported the fact student emotions and communication skills are influenced by other factors such as family and personal factors. Therefore, generalizations cannot be drawn easily. However, the insignificant differences in this study may result from the students in this study being from the Saudi Arabian culture in which they remain under family care until after graduation, as well as all of them receiving a monthly allowance from the university. Therefore, no significant effect of the family or social-related factors was expected. This was supported in previous studies which reported no significant effect of individual factors, such as family or socio-economic status, on Saudi university students' success in their studying (Al-Shawwa et al., 2015). Furthermore, students from different majors were more successful in comprehending their learning materials, and they received the same number of practical sessions that may have brought about their positive learning attitudes. Students from the three fields of study may felt enjoyment working with each other through the PBL techniques, which in turn enables them to discuss the problem effectively and improve their ability to generate and formulate personal opinions. This is in line with other studies (McLean et al., 2006; Alajmi, 2014). The result could also be insignificant due to university students' motivation being less sensitive to contextual factors of the study. In relation to this result, Wigfield et al. (2002) state that a cumulative experience of discrete emotions in the classroom environment can be expected to lead to stability of emotional perceptions regarding specific domains and lifelong learning. The result may also be justified by the fact the students from different discplines received higher classroom support and experienced positive feelings. The result was somehow inconsistent with the finding of Parpala et al. (2006) who proposed that disciplines have differing learning and teaching approaches, practicies and experiences. The results of the mean scores of the students somehow supported the other former studies such as one of Goetz et al. (2010) who stated students experienced different emotional levels in different domains, and such differences may be due to the composition, dynamics, competition, and peer support in classrooms (Goetz et al., 2013).

\section{Conclusion}

This study contributed to the field of education and urged future research to examine the subject matter, using both quantitative and qualitative approaches, in order to enrich the information on students' perception of their study. The data from the student selfreport measures used in the present study atest to their perception of their own study. Moreover, the data in this study was collected from university students living in the Eastern region of Saudi Arabia, so individual factors were not tested due to students 
being financially supported by the university, and the college promoting social skills. Hence, future research could involve other universities from different cultures and countries as these may yield different results. In addition, some previous studies reported no significant influence of the economic status on Saudi university students learning outcomes. Furthermore, the findings of this study may be explained by the fact it was too short. Therefore, future studies can use a longitudinal study approach to enrich the interpretation of relationships among the study variables. The majority of the respondents were undergraduates of a single gender. Thus, future studies can include other students at different levels of study (e.g. postgraduates), and various semesters, to provide more information on the subject matter. Future works can also conduct comparisons of different disciplines based on the variables of this study and other variables. Finally, authors can hereafter delve into the relationship between the variables and actual students' achievements as reflected through the obtained student grades. The independent variable examined in this study is the PBL, the dependent variables are communication skills and emotions towards learning, observed from two groups of students - undergraduate students from the fields of health, engineering and science divided into the PBL and control groups. Through the examination of the variables, this research contributes to the existing literature in four ways; firstly, by determining the effectiveness of the PBL module with regards to communication skills and emotions towards learning among the study sample and, secondly, by developing the PBL module in the Saudi Arabian context. The third contribution refers to the determination of the PBL module's effect on emotions towards learning, which has remained largly untouched in previous literature. The fourth contribution is related to the effect of the PBL module on students' communication skills and emotions towards learning, with comparison between study faculties. The findings contribute to literature through novel information and knowledge, as prior studies concentrated only on some variables and provided general discussions on communication subjects in various settings. The study findings also laid emphasis on the role of the PBL strategy in enhancing students' communication level and enriching positive attitudes towards their learning surroundings. As a consequence, the development of courses using the PBL strategy, both formally and informally, is expected to facilitate student social relationships and their management of emotions, which can in turn boost their learning success.

\section{References}

Abdur-Rohim, A. (2014). Improving students speaking skill through problem-based learning (PBL) strategy. JP3, 3(8), 1-7.

Alajmi, N. (2014). Factors that influence performance in a problem-based learning tutorial. Unpublished Doctoral Thesis. Bond University, Australia. 
Al-Shawaa, L., Abulaban, A., Abulaban, A., Merdad, A., Boghlaf, S., Algethami, A., AbuShanab, J., \& Balkhoyor, A. (2015). Factors potentially influencing academic performance among medical students. Advances in Medical Education and Practice, 6, 65-75. https://doi. org/10.2147/AMEP.S69304

Argaw, A., Haile, B., Ayalew, B., \& Kuma, S. (2017). The effect of problem based learning (PBL) instruction on students motivation and problem solving skills of physics. Eurasia Journal of Mathematics, Science and Technology Education, 13(3), 857-871. https://doi. org/10.12973/eurasia.2017.00647a

Ashley, W., \& Mahnaz, M. (2016). Feedback and feed-forward for promoting problem-based learning in online learning environments. Malaysian Journal of Learning and Instruction, 13(2), 1-41. https://doi.org/10.32890/mjli2016.13.2.1

Augusthy, V. (2016). A comparative study of the learning outcomes and students satisfaction from problem-based learning and lecture-based learning in obstetrics and gynaecology. International Journal of Reproduction, Contraction, Obstetrics and Gynecology, 5(5), 13681374. https://doi.org/10.18203/2320-1770.ijrcog20161001

Awang, H., \& Daud, Z. (2015). Improving a communication skill through the learning approach towards the environment of Engineering classroom. Social and Behavioral Sciences, 195, 480-486. https://doi.org/10.1016/j.sbspro.2015.06.241

Awang, H., \& Ramly, I. (2008). Creative thinking skill approach through problem-based learning: pedagogy and practice in the engineering lassroom. International Journal of Human and Social Sciences, 3(1), 18-23.

Babbie, F., \& Mouton, J. (1998). The ractice of social research. Oxford University Press.

Beausaert, S., Segers, M., \& Wiltink, P. (2013). The influence of teachers teaching approaches on students learning approaches: The student perspective. Educational Research, 55(1), 1-15. https://doi.org/10.1080/00131881.2013.767022

Boer, F., Caten, C., \& Paula, I. (2014). Application of the problem based learning method in the discipline Statistics for Engineering. ASEE 2014 Zone I Conference, April 3-5, 2014, University of Bridgeport, Bridgeport, CT, USA.

Borhan, M. (2012). Problem based learning (PBL) in Malaysian higher education: A review of research on learners experience and issues of implementation. ASEAN Journal of Engineering Education, 1(1), 48-53.

Camp, G. (1996). Problem-based learning: A paradigm shift or a passing fad? Med Educ Online, 1,2. https://doi.org/10.3402/meo.v1i.4282

Celik, P., Onder, F., \& Silay, L. (2011). The effects of problem-based learning on the students success in physics course. Social and Behavioral Sciences, 28, 656-660. https://doi.org/10.1016/j. sbspro.2011.11.124

Chung, P., Yeh, R., \& Chen, Y. (2016). Influence of problem based learning strategy on enhancing students industrial oriented competences learned: An action research on learning weblog analysis. International Journal of Technol Des Educ, 26, 285-307. https:// doi.org/10.1007/s10798-015-9306-3

El-Shaer, A., \& Gaber, H. (2014). Impact of problem-based learning on student critical thinking disposition, knowledge acquisition and retention. Journal of Education and Practice, 5(14), 74-86. 
Erdogan, T., \& Senemoglu, N. (2017). PBL in teacher education: its effects on achievement and self-regulation. Higher Education Research \& Development, 36(6), https://doi.org/10. $\underline{1080 / 07294360.2017 .1303458}$

Faisal, R., Rehman, K., Bahadur, S., \& Shinwari, L. (2016). Problem-based learning in comparison with lecture-based learning among medical students. Journal of the Pakistan Medical Association, 66(6), 650-653.

Felton, J. (1996). Problem-based learning as a training modality in the occupational medicine curriculum. Occup-Med-Oxf, 46(1), 5-11. https://doi.org/10.1093/occmed/46.1.5

Fukuzawa, S., Boyd, C., \& Cahn, J. (2017). Student motivation in response to problem-based learning. Collected Essay on learning and teaching. https://doi.org/10.22329/celt.v10i0.4748

Fung, N. (2013). An exploration of the differing perception of problem-based learning (PBL) from students and facilitators of diverse cultural backgrounds, in the fields of technological and nursing education. ProQuest LLC.

Goetz, T., Frenzel, A., Ludtke, O., \& Hall, N. (2010). Between-domain relations of academic emotion: Does having the same instructor make a difference? The Journal of Experimental Education. https://doi.org/10.1080/00220970903292967

Goetz, T., Ludtke, O., Nett, U., Keller, M., \& Lipnevich, A. (2013). Characteristics of teaching and students emotions in the classroom: Investigating differences across domains. Contemporary Educational Psychology, Elsevier, https://doi.org/10.1016/j.cedpsych.2013.08.001

Haghparast, N., Sedghizadeh, P., Shuler, C., Ferati, D., \& Christersson, C. (2007). Evaluation of student and faculty perceptions of the PBL curriculum at two dental schools from a student perspective: a cross-sectional survey. European journal of dental education: official journal of the Association for Dental Education in Europe, 11(1), 14-22. https://doi. org/10.1111/j.1600-0579.2007.00423.x

Halverson, S. (2003). The cognitive basis of translation universals. Target 15(2), 197-241. https://doi.org/10.1075/target.15.2.02hal

Hämäläinen, W. (2004). Problem-based learning of theoretical computer science. Savannah: Georgia: 34th ASEE/IEEE Frontiers in Education Conference (20-23 September).

Hartman, K., Moberg, C., \& Lambert, J. (2014). Effectiveness of problem-based learning in introductory business courses. Journal of Instructional Pedagogies, 12. https://eric. ed.gov/?id=EJ1097131

Hung, W., Jonassen, D., \& Liu, R. (2008). Problem-based learning. Handbook of Research on Educational Communications and Technology, 3, 485-506.

Kader, Z., Abdullah, N., Anthony, E., Salleh, B., \& Kamarulzaman, R. (2016). Does problembased learning improve problem solving skills? A study among business undergraduate at Malaysian Premier Technical University. International Education Studies, 9(5), 166-172. https://doi.org/10.5539/ies.v9n5p166

Kanet, J., \& Barut, M. (2003). Problem-based learning for production and operations management. Decision Sciences Journal of Innovative Education, 1(1), 99-118. https://doi. org/10.1111/1540-5915.00007

Kinsella, G., Mahon, C., \& Lillis, S. (2017). Using pre-lecture activities to enhance learner engagement in a large group setting. Active Learning in Higher Education, 18 (3), 231-242. https://doi.org/10.1177/1469787417715205 
Jdaitawi: The Effect of Using Problem-Based Learning upon Students' Emotions towards Learning and Levels ...

Krishnan, S., Gabb, R., \& Vale, C. (2011). Learning cultures of problem-based learning teams. Australasian Journal of Engineering Education, 17(2), 67-78. https://doi.org/10.1080/220 $\underline{54952.2011 .11464057}$

Lee, M., \& Kim, D.S. (2005). The Effects of the collaborative representation supporting tool on problem-solving processes and outcomes in web-based collaborative problem-based learning (PBL) environments. Journal of Interactive Learning Research, 16(3), 273-293.

Lin, C., Lu, M., Chung, C., \& Yang, C. (2010). A comparison of problem-based learning and conventional teaching in nursing ethics education. Nursing Ethics, 17(3), 373-382. https:// doi.org/10.1177/0969733009355380

Lindblom-Ylänne, S., Trigwell, K., Nevgi, A., \& Ashwin, P. (2006). How approaches to teaching are affected by discipline and teaching context. Studies in Higher Education 31(3), 285298. DOI: $10.1080 / 030750706080539$

Mandeville, D., Ho, R., \& Valdez, L. (2017). The effect of problem based learning on undergraduate oral communication competency. Journal of College Teaching \& Learning, 14(1), 1-10. https://doi.org/10.19030/tlc.v14i1.9957

Maria, F., \& Anthony, T. (2012). The impact of problem-based learning (PBL) on student attitudes toward science, problem-solving skills, and sense of community in the classroom. Journal of Classroom Interaction, 47(1), 23-30.

McLean, M., Wyk, V., Futre, M., \& Higgins-Opitz, S. (2006). The small group in problem-based learning: More than a cognitive learning experience for first-year medical students in a diverse population. Medical Teacher, 28(4), 94-103. https://doi.org/10.1080/01421590600726987

Mitchell, J., Canavan, B., \& Smith, J. (2010). Problem-based learning in communication systems: Student perceptions and achievement. IEEE Transaction on Education, 1-8. https:// doi.org/10.1109/TE.2009.2036158

Murray-Harvey, R., Curtis, D., Cattley, G., \& Slee, P. (2005). Enhancing teacher education students generic skills through problem-based learning. Journal of teaching Education, 16(3), 257-273. https://doi.org/10.1080/10476210500205025

Nalova, E., \& Shalanyuy, K. (2017). Teaching practice and the development of higher order thinking skills in secondary school students in the North West Region of Cameroon. European Journal of Education Studies, 3(4), 148-160. https://doi.org/10.24940/ijird/2018/ v7/i3/MAR18033

Nur-Izzati, A., Tarmiz, R., \& Rosini, A. (2010). The effect of problem based learning on mathematics performance and affective attributes in learning statistics at form four secondary level. Social and Behavioral Sciences, 8, 370-376. https://doi.org/10.1016/j. sbspro.2010.12.052

Parpala, A., Lindblom-Ylanne, S., \& Rytkonen, H. (2010). Students conceptions of good teaching in three different disciplines. Journal of Assessment \& Evaluation in Higher Education, 36(5), 549-563. https://doi.org/10.1080/02602930903541023

Pekrun, R., Goetz, T., \& Perry, R. (2005). Achievement emotions questionnaire (AEQ): User's manual: Department of Psychology, University of Munich, Munich, Germany.

Peterson, M. (1997). Skills to enhance problem-based learning. Med Edue Online, 2(3), 1-8. https://doi.org/10.3402/meo.v2i.4289 
Raupach, T., Munscher, C., Pukrop, T., Anders, S., \& Harendza, S. (2010). Significant increase in factual knowledge with web-assisted problem based learning as part of an undergraduate cardio-respiratory curriculum. Advances in Health Sciences Education, 15(3), 349-356. https://doi.org/10.1007/s10459-009-9201-3

Savery, J. (2006). Overview of problem-based learning: Definitions and distinctions. Interdisciplinary Journal of Problem-based Learning, 1(1), 9-20. https://doi.org/10.7771/1541$\underline{5015.1002}$

Savery, J., \& Duffy, T. (1995). Problem based learning: An instructional model and its constructivist framework. Educational Technology 35(5), 7-31.

Sekaran, U. (2003). Research Methods for business: A skill building approach: John Willey \& Sons, Ltd.

Selcuk, G., Caliskan, S., \& Sahin, M. (2010). a comparsion of achievement in problem-based, strategic and traditional learning classes in physics. International Journal on New Trends in Education and Their Implications, 4(1), 154-164. www.ijonte,org

Siedel, T., \& Shavelson, R. (2007). Sampling variability of Performance Assessment. Journal of Educational Measurements, 30, 215-230. https://doi.org/10.1111/j.1745-3984.1993.tb00424.x

Spence, J., \& Heilmreich, R. (1983). Achievement related motives and behaviors: In J.T. Spence (Ed.), Achievement and Achievement Motives. San Francisco: Free Press, 1-67.

Stanton, M., Guerin, B, \& Barrett, T. (2017). The transfer of problem-based learning skills to clinical practice. Interdisciplinary Journal of Problem-Based Learning, 11(2). https://doi. org/10.7771/1541-5015.1678

Stentoft, D. (2017). From saying to doing interdisciplinary learning: Is problem-based learning the answer? Active Learning in Higher Education, 18(1), 51-61. https://doi. org/10.1177/1469787417693510

Strobel, J., \& Van-Barneveld, A. (2009). When is PBL more effective? A meta-synthesis of meta-analyses comparing PBL to conventional classrooms. The Interdisciplinary Journal of Problem-Based Learning, 3(1), 44-58. https://doi.org/10.7771/1541-5015.1046

Struthers, C., Perry, R., \& Menec, V. (2000). An examination of the relationship among academic stress, coping, motivation, and performance in college. Research in Higher Education, 41(5), 581-592. https://doi.org/10.1023/A:1007094931292

Sungur, S., \& Tekkaya, C. (2006). Effects of problem-based learning and traditional instruction on self-regulated learning. Journal of Educational Research, 99(5) 307-317. https://doi. org/10.3200/JOER.99.5.307-320

Tarmizi, R., Tarmizi, M., Lojinin, N., \& Mokhtar, M. (2010). Problem based learning: Engaging students in acquisition of mathematical competence. Social and Behavioral Sciences, 2, 4683-4688. https://doi.org/10.1016/j.sbspro.2010.03.750

Thabet, M., Taha, E., Abood, S., \& Morsy, S. (2017). The effect of problem-based learning on nursing students decision making skills and styles. Journal of Nursing Education and Practice, 7(6), 108-116. https://doi.org/10.5430/jnep.v7n6p108

Vujicic, L., Tambolas, A., \& Navratil, T. (2018). Social environment and the quality of social interactions: The perspective of future preschool teachers. Croatian Journal of Education, 20(1), 95-111. https://doi.org/10.15516/cje.v20i0.3051 
Webb, A., \& Moallem, M. (2016). Feedback and feed-forward for promoting problem based learning. In G. Chamblee \& L. Langub (Eds.), Proceedings of Society for Information Technology \& Teacher Education International Conference (pp. 434-442). https://www. learntechlib.org/primary/p/171712/

Wigfield, A., Battle, A., Keller, L., \& Eccles, J. (2002). Sex-differences in motivation, selfconcept, career aspiration, and career choice: Implications for cognitive development: In A. McGillicuddy-De Lisi, \& R. De. (Eds.), Advances in applied developmental psychology, Vol. 21. Biology, society, and behavior: The development of sex differences in cognition (pp. 93-124). Ablex Publishing.

Yates, W., \& Gerdes, T. (1996). Problem-based learning in consultation psychiatry. General Hospital Psychiatry, 18(3), 139-144. https://doi.org/10.1016/0163-8343(96)00022-9

Yew, E., \& Goh, K. (2016). Problem-based learning: An overview of its process and impact on learning. Health Professions Education, 2, 75-79. https://doi.org/10.1016/j.hpe.2016.01.004

\section{Malek Jdaitawi}

Self-Development Department, Deanship of Preparatory Year and Supporting Studies,

Imam Abdulrahman Bin Faisal University

University Street, 34221, Rakah, Dammam, Saudi Arabia

mtmustafa@iau.edu.sa 


\section{Učinak problemskoga učenja na emocije studenata prema učenju i razinu komunikacijskih vještina u tri različite discipline}

\section{Sažetak}

Tijekom posljednjih godina nastavnički kadar motiviran je za angažiranje studenata u različitim oblicima komunikacije. Ova kvazieksperimentalna studija predstavlja primjenu pristupa problemskoga učenja $(P U)$ u okolini predavaonice prve godine studija s ciljem razvijanja komunikacijskih vještina studenata i promicanja pozitivnih emocija prema učenju. Istraživanje je provedeno sa studentima zdravstvenoga, inženjerskoga i znanstvenoga smjera. Studenti su podijeljeni u dvije skupine, eksperimentalnu (90 studenata) $i$ kontrolnu skupinu (90 studenata). Trajalo je četiri tjedna tijekom kojih se modulu poučavalo 180 studenata prve godine u obje skupine. Rezultati pokazuju značajan utjecaj problemskoga pristupa učenju na komunikacijske vještine studenata i njihove emocije prema učenju. Na kraju su izvedeni zaključci.

Ključne riječi: emocije prema učenju; inženjerski smjer; sveučilišno okruženje; zdravstveni smjer; znanstveni smjer

\section{Uvod}

Prošla su desetljeća svjedočila istraživačkim pokušajima utvrđivanja uspješnoga učenja učenika na svim razinama. U stvari, većina istraživanja u ovom kontekstu povezuje uspješne učenike sa psihološkim, okolinskim i socijalnim čimbenicima, kao i uz pristupe učenju i poučavanju (npr. Nalova i Shalanyuy, 2017; Stentoft, 2017; Erdogan i Senemogly, 2017; Vujicic, Tambolas, i Navratil, 2018). U posljednje vrijeme edukatori su osmislili nekoliko strategija poučavanja za preoblikovanje sadržaja kurikula i premošćivanje praznine između zahtjeva učionice i života (Beausaert, Segers i Wiltink, 2013). Dodatno, prakse poučavanja krucijalne su za procese učenja i poučavanja - takve prakse opisane su kao učiteljske aktivnosti u učionici, uključujući metode poučavanja, procjene i upravljanja. $U$ tom smislu, istraživači su povezali prakse poučavanja s uspješnim akademskim postignućima studenata i njihovim komunikacijskim vještinama, sposobnostima da budu pronicljivi i kritični u svojem načinu razmišljanja (Nalova i Shalanyuy, 2017; Seidel i Shavelson, 2007; Mandeville, 
Ho i Valdez, L., 2017). Stoga, može se ustvrditi da su procesi poučavanja, materijali i procjena, značajni za poboljšanje ishoda učenja studenata i njihovo stjecanje vještina mišljenja višega reda.

U institucijama visokog obrazovanja još uvijek postoje pitanja pristupa učenju, posebno za studente prve godine. U svijetu učenja, problemsko učenje (PU) široko je prihvaćeno kao način poučavanja u različitim disciplinama (Chung, Yeh i Chen, 2016; Hung, Jonassen i Liu, 2008). U stvari, to je jedna od najintegriranijih i najsuvremenijih metoda poučavanja koja je u literaturi naglašavana zbog svoje primjerenosti i učinkovitosti u unaprjeđivanju učeničkih osobnih, emocionalnih, socijalnih i kognitivnih vještina. PU potiče intelekt, komunikaciju, mišljenje višega reda, rješavanje problema, socijalne vještine i akademsko postignuće studenata (El-Shaer i Gaber, 2014; Argaw, Haile, Ayalew i Kuma, 2017; Santon, Guerin i Barrett, 2017). Drugim riječima, korištenje PU-a i drugih učinkovitih strategija koje unaprjeđuju stavove studenata prema učenju krucijalno je u institucijama visokoga obrazovanja. Posljedično, PU uvelike se primjenjuje u nekoliko obrazovnih disciplina zbog toga što može potaknuti sposobnosti učenja studenata (Hung i sur., 2008). Većina studija ističe pozitivni doprinos PU-a učenju i poučavanju i, važnije, studentskim vještinama učenja, o čemu svjedoči literatura (npr. Stentoft, 2017; Argaw i sur., 2017; Webb i Moallem, 2016). Prema Hamalainenu (2004), PU utječe na povećavanje sposobnosti studenta koje su važne za rješavanje problema i kritičko mišljenje, tj. komunikacije, interakcije, suradnje i kognicije. Zaključno, PU neprocjenjivo je za povećavanje misaonih razina studenata $i, u$ konačnici, njihovo visoko akademsko postignuće. Ipak, bez obzira na prije spomenute studije i njihove rezultate, istraživanja uspješnoga postignuća studenata zbog učinaka PU-a još su uvijek rijetka (Yew i Goh, 2016; Stentoft, 2017). Sve navedeno očituje se u nedostatku pažnje koja se pridaje primjeni ovoga modula u kontekstu sveučilišnoga obrazovanja. Štoviše, istraživanja utjecaja PU-a na komunikacijske vještine studenata i njihove emocije prema učenju gotovo su nepostojeća. Stoga, zbog manjka primjerenih studija u literaturi, ovo istraživanje pokušava ponuditi potencijalno rješenje pitanja razvijajući modul koji bi poboljšao komunikacijske vještine studenata na sveučilištu i razvio pozitivne emocije prema učenju. Ova studija istražuje komunikacijske jedinice na različitim studentskim razinama (studenti pripremne godine).

\section{Razvoj komunikacijskih vještina studenata kroz PU}

Sveučilišta imaju općenitu potrebu prenijeti i razviti osobne i prenosive vještine studentima, kako bi ih pripremila i pomogla im da odaberu buduće karijere poput one zdravstvenih radnika, inženjera ili znanstvenika (Mitchell, Canavan, i Smith, 2010). Razlog tomu je što su većini studenata, unatoč potrebi za stjecanjem čvrste osobnosti te socijalnih $\mathrm{i}$ kognitivnih vještina, $\mathrm{u}$ tim područjima vještine i sposobnosti još uvijek manjkave. Istraživanja su zato usmjerena na ispitivanje uloge komunikacije i društvene interakcije u svijetu poučavanja i učenja, posebno među studentima prve godine na sveučilištima (Awang i Daud, 2015). Dodatno, različite su vrste komunikacije (verbalne, 
neverbalne vještine i vještine pisanja) koje omogućuju angažman studenata s vlastitim kolegama i profesorima pri razvijanju i poboljšanju znanja predmetne građe. Stoga je PU dosegnulo popriličnu razinu popularnosti zbog svoje učinkovitosti u učenju i poučavanju metoda u različitim disciplinama visokoga obrazovanja (Chung i sur., 2016). Specifičnije, PU odnosi se na pristup koji pomaže studentima razvijati vještine učenja koje su usmjerene na njih, što proizlazi iz stajališta da je učenje proces unutar kojega je učenik aktivno uključen u razvoj novoga znanja na osnovi prijašnjeg.

PU omogućuje studentima da iskoriste pokretače iz problemskoga slučaja ili situacije kako bi uspostavili fokus učenja. Nakon toga, neovisno, prolaze kroz samousmjeravajuće učenje, prije rasprave s grupom ili rafiniranja novostečenoga znanja (Awang i Daud, 2015). Štoviše, PU nije ograničeno samo na rješavanje problema, već obuhvaća i primjerene probleme kako bi maksimiziralo spoznajne procese i razmišljanje studenata. Štoviše, grupno učenje potiče učenje za znanje, kao i ostale osobine studenata (komunikacijske vještine, timski rad, rješavanje problema, neovisnu odgovornost za učenje, podjelu informacija i poštivanje kolega i profesora) (Mitchell i sur., 2010; Major, 2001). Nadalje, PU omogućava studentima stjecanje i usavršavanje praktičnih vještina, dobivanje povratne informacije od kolega i profesora, njihovoga vodstva i podrške te razvijanje suradnje i vještina integracije u skupini. Problemsko učenje poboljšava komunikacijske sposobnosti, vještine rješavanja problema, timskoga rada i kreativnoga razmišljanja, kao i vještine stjecanja znanja (Awang i Daud, 2015; Mitchell i sur., 2010; Selcuk, Caliskan i Sahin, 2010; Tan, 2003). Studenti stječu nove informacije kroz samousmjereno učenje u kojem su odgovorni za prikupljanje informacija iz različitih izvora učenja. Studenti surađuju, raspravljaju, uspoređuju i revidiraju te međusobno raspravljaju o naučenom.

Iako još uvijek rijetke, studije su pokazale da je PU učinkovito u razvijanju takvih vještina među studentima na sveučilištu. Za početak, Santon i suradnici (2017) ispitali su učinak prijenosa vještina problemskoga učenja na kliničku praksu 19 poslijediplomskih studenata. Rezultati pokazuju zamjetno poboljšanje vještina mišljenja, učinkovitu komunikaciju s kolegama i pacijentima kao i poboljšanje njihovih kliničkih vještina. Mandeville i suradnici (2017) proučavali su učinak problemskoga učenja na kompetenciju u usmenoj komunikaciji među 80 dodiplomskih studenata na kineziološkim kolegijima. Rezultati upućuju na poboljšanje komunikacijskih sposobnosti studenata tijekom studiranja. Kako bi ilustrirali učinkovitost pristupa PU-a, Chung i suradnici (2016) ispitali su utjecaj strategije PU-a na povećanje ishoda učenja studenata s obzirom na industrijski orijentirane kompetencije. Studente u eksperimentalnoj skupini poučavalo se strategijom PU-a, a u kontrolnoj skupini tradicionalnom strategijom. Rezultat studije pokazao je da su aktivnosti poučavanja postale zanimljivije nakon primjene PU-a te su ishodi učenja povećani. Awang i Daud (2015) istražili su učinak PU-a kao metode za povećanje komunikacijskih vještina studenata. Njihova kvazieksperimentalna studija uključivala je 60 studenata inženjerstva koji su bili podijeljeni u dvije skupine, tj. eksperimentalnu i kontrolnu, u osmotjednom istraživanju. Rezultati navedene studije potvrđuju učinak PU-a na komunikacijske vještine studenata i njihov pristup učenju. 
U svojoj studiji miješanih metoda, Abdur-Rohim (2014) ispitao je učinak problemske strategije u poboljšanju govornih vještina među 46 studenata. Kako bi procijenio vještine studenata, Abdur-Rohim (2014) koristio je četiri instrumenta. Rezultati su pokazali poboljšanje aritmetičkih sredina govornih vještina studenata nakon testiranja u usporedbi s vrijednostima istih prije testiranja. U sličnom istraživanju, Mitchel i suradnici (2010) otkrili su da se motivacija i percepcija studenata povećava nakon primjene PU modula u njegovoj studiji, koja je evaluirala kolegij komunikacijskoga sustava uz upotrebu PU-a. Također, autori Tarmizi, Tarmizi, Lojinin i Mokhtar (2010) proveli su kvazieksperimentalnu studiju koja je uključivala 24 studenta i pokušali istražiti utjecaj PU-a na poboljšanje učenja matematike, kompetencije i razmišljanja o komunikaciji studenata. Nisu pronašli značajnu razliku između skupine PU-a i kontrolne skupine u kontekstu matematike. Ipak, postojala je značajna razlika između PU i kontrolnih skupina u kontekstu angažmana i mentalnih nastojanja. Stoga, PU je učinkovito u poboljšanju komunikacijskih vještina studenata.

\section{Promicanje pozitivnih emocija studenata prema PU-u}

Ovo istraživanje usmjereno je na trenutačno obrazovanje studenata pripremne godine kako bi im se pomoglo u daljnjem obrazovanju. Ovo nastojanje povezano je sa sve većim interesom za kurikulne reforme koje se usredotočuju na razvoj kompetencija, akademskih vještina studenata i predmetne građe. U novijim istraživanjima naglašava se radno mjesto i socijalne vještine. $U$ vezi $s$ tim, u usporedbi s konvencionalnom inteligencijom, značajan se utjecaj pridaje metodama poučavanja te emocionalnim i socijalnim vještinama u ostvarenju raznih karijera, obrazovanja i tipova osobnoga postignuća (Mitchell i sur., 2010; Pekrun, Goetz i Perry, 2005). Bez obzira na dokaze koji govore o važnosti PU-a u dosadašnjoj literaturi (Kanet i Barut, 2003; Maria i Anthony, 2012; Strobel i Barneveld, 2009), istraživanje njegova utjecaja na motivaciju još je uvijek nedostatno (Fukuzawa, Boyd i Cahn, 2017). Savery (2006) je također dao doprinos literaturi o PU-u opisujući ga kao pristup poučavanja koji uključuje učenike $\mathrm{u}$ istraživanje, integraciju teorije i praktičnih upotreba (primjena znanja i vještina) $\mathrm{u}$ rješavanju problema (str. 9). Iako se u posljednje vrijeme nekoliko studija fokusiralo na učinak PU-a na ishode učenja studenata poput postignuća, studentskog zadovoljstva, percepcija, vještina razmišljanja, komunikacije i samoregulacije, studija posvećena promociji učenja emocija studenata upotrebom strategije problemskoga učenja ne postoji. Ipak, pozitivan učinak ovoga pristupa primijećen je i o njemu se izvještavalo, makar samo indirektno. Na primjer, u istraživanju Argau i suradnika (2017) ispitan je učinak problemskoga učenja na motivaciju studenata i vještine rješavanja problema u fizici. Kvazieksperimentalna studija provedena je na uzorku koji je obuhvaćao 81 studenta. Rezultati nisu otkrili značajan učinak na istraživačku varijablu između eksperimentalnih i kontrolnih skupina. Erdogan i Senemoglu (2017) ispitivali su učinkovitost problemskoga učenja na akademsko postignuće i samoregulaciju studenata. 57 studenata sudjelovalo je u studiji koja je obuhvaćala jezično testiranje i evaluacijski 
kolegij na Tehničkom sveučilištu Bliskog istoka u Turskoj. Rezultati studije otkrili su kako je problemsko učenje bilo učinkovito za studentsko znanje i postignuće, ali nije utjecalo na samoregulaciju studenata. Ashley i Mahnaz (2016) ispitali su učinak strategije problemskoga učenja na promicanje povratne informacije i informacije predviđanja $u$ kontekstu online učenja među jedanaest dodiplomskih studenata. U njihovoj studiji mješovite metode rezultat je pokazao kako PU strategija podržava postignuće studenata te da ih je motivirala i pružila im mogućnost za daljnje napredovanje. El-Shaer i Gaber (2014) istražili su učinak pristupa problemskoga učenja na kritičko mišljenje i druge varijable među 200 studenata sestrinstva na Mansoura sveučilištu. Rezultat je pokazao kako su studenti u PU skupini poboljšali svoje vještine kritičkoga mišljenja tijekom perioda intervencije. Također, Maria i Anthony (2012) ispitali su učinak problemskoga učenja na stav studenata prema znanosti, kao i rješavanje problema i osjećaj za zajednicu u predavaonici na uzorku od 48 studenata. Ipak, rezultati upitnika i refleksivnih zapisa studenata, kao i opservacije profesora, pokazuju razvijenije vještine rješavanja problema i pozitivne stavove prema znanosti i okolini učenja. Studija Halverson’s (2003) otkrila je kako PU-e izaziva negativne emocije među studentima, uključujući njihovu nesigurnost, stres i bespomoćnost jer pruža konkretne i realistične aktivnosti. Slično tomu, Struthers, Perry i Menec (2000) izvještavaju da studenti angažirani u problemskim aktivnostima imaju bolju izvedbu u usporedbi sa svojim kolegama fokusiranim na emocije. Dodatno, PU pozitivno utječe na studentsku percepciju vlastite sposobnosti da iskoriste mehanizam rješavanja problema usredotočen na emocije. Nadalje, proces upravljanja na studente fokusiranoga pristupa učenju, uz realne probleme, omogućuje razvoj sposobnosti upravljanja negativnim emocionalnim reakcijama povezanim uz stres visoke razine. Povrh svega, čini se kako PU potiče studentsku motivaciju pa se oni tako osjećaju više uključenim u stvarne situacije, a ne samo u teorije (Borhan, 2012). Zaključno, PU može biti povezano s posljedičnim pozitivnim i negativnim rezultatima.

\section{Učinak područja studiranja na korištenje PU-a}

Primarni je cilj obrazovanja pomoći u boljem učenju i stjecanju mišljenja višega reda, što je neprocjenjivo za buduće karijere i živote studenata. Stoga, metoda PU-a ima ključnu ulogu u ostvarivanju snažne i trajne motivacije za učenje i rješavanje problema, kreativno mišljenje i kritičko razmišljanje (Fukuzawa i sur., 2017; El-Shaer i Gaber, 2014). Pristup PU-a povezan je s primjerenim pristupom koji omogućuje povezivanje predznanja studenata s novostečenim znanjem dok rade u timovima na rješavanju aktualnih problema (Fukuzawa i sur., 2017). Većina istraživanja posvećenih PU-u svjedočila je pozitivnim učincima na vještine rješavanja problema studenata (Argau i sur., 2017), komunikaciju, timski rad i angažman kao i sveopće kognitivne vještine (rješavanje problema i kreativno mišljenje) (Stentoft, 2017; El-Shaer i Gaber, 2014). Također, PU potiče studente na interakciju u njihovoj okolini učenja (Sungur i Tekkaya, 2006), stoga se može zaključiti da PU ima pozitivan utjecaj na različite aspekte studentskoga učenja u području zdravstvenoga obrazovanja, kako su pokazali 
Raupach i Digerleri (2010) i Lin i Digerleri (2010), inženjerskoga obrazovanja, prema rezultatima istraživanja Awang i Ramly (2008), kao i u znanstvenom obrazovanju, prema Celik, Onder i Silay (2011). Pristup se može koristiti u poučavanju malih skupina koje integriraju stjecanje znanja i razvoj generičkih vještina, stavova i emocija. Primjer navedenoga nalazi se u prezentaciji kliničkih materijala za poticanje učenja među studentima i njihovo razumijevanje relevantne znanstvene teorije i principa kliničke prakse. U kontekstu znanosti primijećeno je da studenti tragaju za prilikama u kojima bi prakticirali kolegije i sudjelovali u raspravi o svojem znanju i tako razmjenjujući informacije unutar skupine nadoknadili nedostatke u vlastitom znanju. Naposljetku, u inženjerstvu su praktične vještine studenata povećane, posebno među novacima. Iako je metoda PU-a pokazala mnoge prednosti u usporedbi s drugim metodama učenja, malo se istraživanja bavi učinkom PU-a u različitim disciplinama, stoga će ova studija pridonijeti korpusu literature koja govori o istraživanju različitih učinaka PU-a na studente u tri različite discipline.

U literaturi modula PU-a o učincima na komunikacijske vještine i emocije studenata prema učenju, autori, uključujući Hartmana, Moberga i Lamberta (2013), Awang i Dauda (2015) i Tarmizi i suradnike (2010), pozivaju na provođenje daljih studija. Ovo se posebno odnosi na istraživanja koja se fokusiraju na učinak PU-a među studentima prve godine sveučilišnog studija, pri čemu se naglašava potreba istraživanja same tehnike problemskoga učenja. Stentoft (2017) je proveo istraživanje s ciljem ispitivanja svrhe i načela interdisciplinarnoga i problemskoga učenja. Rezultat pokazuje da je problemsko učenje kao potencijalno atraktivna pedagoška praksa moguće primijeniti u raznim disciplinama. Fukuzawa, Boyd i Cahn (2017) ispitivali su učinak studentske motivacije kao reakcije na problemsko učenje među 49 studenata različitih kolegija na sveučilišnoj razini. Rezultat studije pokazuje da se motivacija studenata za problemsko učenje povećala prema kraju studija. U eksperimentalnom istraživanju Thabet i suradnici (2017) ispitivali su učinak problemskoga učenja na donošenje odluka i stilove donošenja odluka studenata sestrinstva. 84 studenta sestrinstva bilo je uključeno u istraživanje i podijeljeno u dvije skupine, PU i kontrolnu skupinu. Rezultati su pokazali kako su studenti u skupini PU unaprjeđivali vlastito donošenje odluka i stilove u usporedbi s kontrolnom skupinom. Na primjer, Faisal, Rehman, Bahadur i Shinwari (2016) ispitivali su učinkovitost problemskoga učenja među 146 studenata medicine s Rehman medicinskoga koledža u Bakistanu. Rezultati aritmetičkih sredina akademskoga postignuća studenata u PU skupini pokazali su se višima od onih njihovih kolega u kontrolnoj skupini. Isto tako, rezultati istraživanja Faisal i suradnici (2016) upućuju na pozitivan učinak PU-a kao primijenjenom načinu poučavanja. Augusthy (2016) je usporedio predavaonicu u kojoj se primijenilo PU-e s tradicionalnom predavaonicom među studentima medicine. Kao rezultat, iako su obje skupine studenata, ona poučavana pristupom PU-a i tradicionalnim predavačkim pristupom, pokazale bolje ishode u prisjećanju, analitičkom i kritičkom mišljenju te rješavanju problema, PU skupina bila je učinkovitija u zadovoljstvu i motivaciji od studenata u skupini u 
kojoj je primijenjen predavački pristup učenju. U svojem kvazieksperimentalnom istraživanju, Kadir, Abdullah, Anthony, Salleh i Kamarulzaman (2016) ispitali su komparativni učinak PU-a na rješavanje problema između eksperimentalne i kontrolne skupine. Studenti u eksperimentalnoj grupi rješavali su četiri problema na osnovi kojih su učinjene procjene. Studenti u kontrolnoj skupini učili su tradicionalnom metodom. Rezultati studije pokazuju bolju sposobnost rješavanja problema studenata u eksperimentalnoj od one koju su pokazali studenti u kontrolnoj skupini. Boer, Caten i Paula (2014) proveli su istraživanje među studentima inženjerstva kako bi ispitali učinak PU pristupa na kolegij Statistika. Rezultati njihova istraživanja upućuju na to da studenti i profesori pokazuju veliko zadovoljstvo primjenom PU-a u procesu učenja/ poučavanja. Nadalje, rezultati ukazuju na to da $89 \%$ studenata ima koristi od aktivnosti koje nudi PU. Hartman i suradnici (2013) istraživali su učinak problemskoga učenja na učenje u uvodnim kolegijima poslovanja među studentima ekonomije. Korišten je dizajn predtesta i posttesta kako bi se usporedili pozitivni učinci problemskoga učenja na toleranciju dvosmislenosti kod studenata i njihovo snalaženje u problemskim i emotivno zahtjevnim situacijama. Dobiveni rezultati pokazuju kako PU pozitivno utječe na studentske percepcije vlastite sposobnosti da koriste emotivno snalaženje, a ukazuju da PU negativno utječe na studentsku toleranciju prema dvosmislenosti. Celik i suradnici (2011) ispitali su učinak PU-a kao metode koja utječe na uspjeh studenata u kolegiju Fizika. Njihova kvazieksperimentalna studija uključivala je 44 studenta koji su bili podijeljeni u dvije skupine, tj. 20 studenata u eksperimentalnoj i 24 studenta u kontrolnoj grupi. Rezultati su pokazali da su studenti koji su učili u PU skupini pokazali bolje postignuće iz Fizike od studenata u kontrolnoj grupi, koji su učili predavačkim pristupom.

Zaključno, većina studija koje su do danas ispitivale učinke PU strategije fokusiralo se na medicinu, inženjerstvo, znanost, fiziku i umjetnost neovisno jedna o drugoj ili su ih uspoređivale u jednom istraživanju. Stoga, ovo istraživanje prvenstveno doprinosi korpusu literature koja govori o sličnim istraživanjima ispitujući utjecaj modula PU-a na komunikacijske vještine i emocije prema učenju studenata prve godine. Na taj se način omogućava razumijevanje značaja žarišnih koncepcija za uspješno akademsko postignuće studenata. S obzirom na navedeno, postavljena su tri glavna pitanja:

1. Postoje li značajne razlike između PU eksperimentalne skupine i kontrolne skupine na razini komunikacijskih vještina?

2. Postoje li značajne razlike između eksperimentalne skupine i kontrolne skupine na razini emocija vezanih za učenje?

3. Doprinosi li čimbenik područja studiranja učinku PU-a na komunikacijske vještine studenata i emocije prema učenju?

Iz navedenih pitanja proizlaze sljedeće tri hipoteze: PU ima učinak na komunikacijsku razinu studenata; PU utječe na studentske emocije prema učenju i učinak PU bit će različit u različitim područjima studiranja. 


\section{Metodologija \\ Nacrt istraživanja}

U ovoj studiji koristili smo kvazieksperimentalni pristup i kvalitativnu istraživačku metodu kojom smo proveli studiju slučaja i opisali opservacije istraživača (Babbie i Mouton, 2001). Prema Sekaran (2003) istraživačka metoda primjerena je za prikupljanje iscrpnih podataka o stavovima i uvjerenjima ispitanika, posebno kada su uvelike zastupljeni u populaciji.

\section{Uzorak i postupci}

Uzorak ispitanika čine studenti pripremnoga koledža na Sveučilištu Abdulrahman Bin Faisal u istočnoj pokrajini Saudijske Arabije. Pripremna godina koledža bila je primjerena za istraživanje jer uključuje studente raznih fakulteta, poput onih zdravstvenoga, inženjerskoga i znanstvenoga smjera, kao i činjenica da je spomenuti koledž bio blizu istraživaču pa se eksperiment mogao provesti prema postavljenim zahtjevima studije. Nadalje, pripremni koledž odabran je zato što obuhvaća studente različitih razina sposobnosti, ali istoga socijalnog, kulturološkog i ekonomskog statusa. Sudionici studije su Saudijci iz istočne pokrajine Saudijske Arabije istih kulturoloških i socijalnih karakteristika. S obzirom na ekonomske čimbenike, sveučilište je smješteno u razvijenom području te ga subvencionira Vlada, pa tako svi studenti dobivaju mjesečnu potporu koja zadovoljava njihove osobne, socijalne i akademske potrebe. Nadalje, prijašnje studije podržavaju činjenicu da kulturološki i ekonomski čimbenici ne utječu na uspjeh PU-a u sveučilišnom okruženju budući da PU pomaže studentima u međusobnoj suradnji (Krishnan, Gabb i Vale, 2011). Stoga, prema mišljenju istraživača i njegovih kolega, navedeni čimbenici ne bi trebali utjecati na rezultate studije i nije ih se uzimalo u obzir prilikom određivanja ciljeva istraživanja.

Stotinu osamdeset studenata iz tri razine pripremne godine činili su uzorak ispitanika koji su uključeni u istraživanje. Korišteno je svrsishodno uzorkovanje utemeljeno na sklonosti za sudjelovanje u istraživanju studenata fakulteta zdravstvenog, inženjerskog i znanstvenog smjera (2017.-2018.). Jezična kompetencija ima ključnu ulogu u odabiru tih smjerova budući da se nastava obično odvija na engleskom jeziku. Uzorak od 180 studenata bio je odabran i nasumično kategoriziran u PU skupinu (90 studenata) i kontrolnu skupinu (90 studenata), od čega su 30 studenata s fakulteta zdravstva, 30 s inženjerstva i preostalih $30 \mathrm{~s}$ fakulteta znanosti. Ova podjela odgovara uobičajenoj veličini grupe u obrazovnom sustavu Saudijske Arabije. Odabirom studenata iz tri studijska područja (zdravstva, inženjerstva i znanosti) nastojalo se u istraživanju ne zanemariti ni jednog studenta te kontrolirati učinak studijskoga područja na rezultate. Nadalje, u uzorak su uključeni studenti tri smjera pripremnoga koledža jer je isti osnovna godina za sve sveučilišne studente. Također, odabrani studenti pohađali su iste kolegije do vremena eksperimenta. Svi studenti koji su maturirali u području zdravstva, inženjerstva i znanosti slušali su iste obavezne predmete kao uvjet za upis 
na sveučilište. Studenti su u prosjeku imali 19 godina i bili na drugom semestru studija. Eksperimentalne i kontrolne skupine bile su izložene PU-u i tradicionalnom pristupu četiri tjedna, ispunjavale predtest prije učenja i posttest nakon isteka četiri tjedna istraživanja. Studenti su u PU-u upoznati s postupcima i dodijeljene su im aktivnosti u svakom pojedinom dijelu nastave kako bi se uštedjelo vrijeme. U provedenom istraživanju nastavnim procesom bile su obuhvaćene četiri teme unutar određene nastavne cjeline iz kolegija Samorazvoj. Svaka tema obrađivala se u okviru dvosata. U jednom dvosatu kombiniralo se nekoliko koraka strategije PU-a i učeničkih aktivnosti. Postupci poučavanja u kontrolnoj skupini obuhvaćeni su istom tradicionalnom metodom u kojoj se studente poučava predavanjima, zadavanjem tematskoga sadržaja i principa, što studente stavlja u ulogu pasivnih učenika. Eksperimentalna grupa učila je primjenom PU-a. Problemska orijentacija, primjena metode i procjene strategije neki su od postupaka i procesa usvojenih tijekom ovoga istraživanja. Ova tri postupka primijenjena su u svakoj pojedinoj cjelini kako bi se postigli ishodi programa. Tijekom četiri tjedna primjene pristupa PU-a studenti su trebali riješiti četiri problema vezana uz četiri zadane teme. Primjena PU-a u ovom istraživanju provedena je uporabom sustava za upravljanje učenjem (webCT ili sada Balckboard learning System), kroz učitavanje materijala učenja poput power-point prezentacija, refleksivnih dnevnika, videa i slika o skupini. Na početku svake PU nastavne cjeline studenti su bili podijeljeni u skupine i dodijeljen im je drugi voditelj za različit problem, te su bili angažirani u aktivnom učenju i raspravi o problemu prezentiranom u obliku videozapisa povezanoga s četiri zadane teme. Studentima su predstavljeni dodatni slikovni prikazi teme i dan uvid u relevantna pitanja vezana uz temu. Tijekom nastave studenti su raspravljali o problemu i davali povratne informacije, izvještavali o vlastitim aktivnostima i odgovarali na pitanja predavača. Prije početka nastave predavač je predvidio dijelove koji zahtijevaju najviše rasprave i objašnjenja. U završnom dijelu studenti su upotrijebili znanje stečeno upotrebom strategije PU-a, dali povratne informacije i evaluirali rad. Predavač je osigurao dodatne materijale kako bi studentima olakšao razumijevanje i stjecanje znanja te zadao zadatke vezane uz temu.

\section{Mjere ishoda}

Komunikacijske vještine mjerene su uporabom ankete komunikacijskih vještina koju su razvili Chung i suradnici, 2016. godine (Chung i sur., 2016). Razvijeno je osamnaest čestica na skali Likertova tipa koje su obuhvaćale ključne značajke komunikacijskih vještina. Čestice su: „Razumijem kako se sugovornik osjeća čitajući njihove izraze lica;” „Pazim na ono što drugi govore jer ljudi mogu imati različita stajališta;” „Stavljam se u poziciju drugoga dok s njim razgovaram". Od studenata se zahtijevalo da odgovore na osamnaest čestica koristeći Likertovu skalu od pet stupnjeva, u rasponu od 1 (izrazito neslaganje) do 5 (izrazito slaganje). Ova skala odabrana je zbog svoje unutarnje pouzdanosti, značajne valjanosti i prijašnjega korištenja (Chung i sur., 2016), $s$ dobivenim Cronbach alpha-koeficijentom od 0,83. Za mjerenje konstrukta emocija 
prema učenju koristila se mjera učenje povezano s emocijama koju su predložili Pekrun, Goetz i Perry (2005). Sastoji se od osam čestica fokusiranih na mjerenje studentskih emocija na nastavi pri čemu se od ispitanika zahtijevalo da odgovore na čestice raspoređene na petostupanjskoj Likertovoj skali, od 1 (izrazito neslaganje) do 5 (izrazito slaganje). Čestice su uključivale: „Radujem se učenju;” „Optimističan/na sam da ću dobro napredovati u učenju;” „Izrazito se nadam da će moje sposobnosti biti dovoljne". Čestice su usredotočene na emocije koje su doživjeli studenti na nastavi. Cronbachov koeficijent čestica bio je 0,85 , što ukazuje na zadovoljavajuću unutarnju konzistentnost.

\section{Analiza}

Cronbachov koeficijent pouzdanosti za anketu komunikacijskih vještina bio je 0,801 , a za emocije prema učenju 0,807 . Budući da su rezultati premašili standardnu vrijednost od 0,80 unutarnje konzistentnosti mjera, smatraju se prihvatliivima. Tablice 1. i 2. prikazuju vrijednosti deskriptivne statistike poput aritmetičke sredine i standardne devijacije za predtest i posttest.

Tablica 1.

Tablica 2.

$\mathrm{Na}$ osnovi rezultata početne analize, statistički značajne razlike u aritmetičkim sredinama ustanovljene su između PU i kontrolnih skupina na podatcima dva predtesta zavisnih varijabli. Razlike aritmetičkih sredina rezultata predtesta komunikacije (PU aritmetička sredina grupe $=2,79, \mathrm{SD}=.332$; aritmetička sredina kontrolne grupe $=$ $3,02, \mathrm{SD}=.339)$ bila je značajna $(\mathrm{F}=8,409, \mathrm{p}=.006<.05)$. Na osnovi ovih rezultata, analiza tipova varijabli (zavisnih i nezavisnih) provedena je upotrebom ANCOVA (analiza kovarijance). ANCOVA je omogućila proučavanje glavnih neovisnih varijabli (eksperimentalne i kontrolne skupine), sa i bez kovarijance. Nadalje, ANCOVA kontrolira čimbenike koji bi utjecali na rezultat studije. Kako bismo bliže ispitali statistički značajnu razliku aritmetičkih sredina varijabli, proveli smo analizu varijance koristeći rezultate posttesta kao zavisne varijable nakon postavljanja rezultata predtesta kao kovarijance. Kontrola rezultata predtesta kao kovarijance može povećati statističku značajnost smanjujući neočekivanu varijancu u rezultatima posttesta. Više specifično, tablica 3 prikazuje rezultate dobivene ANCOVA-om. Rezultat u tablici dokazuje statistički značajnu razliku aritmetičkih sredina između dvije grupe studenata (PU i kontrolne skupine) u odnosu na komunikacijske vještine. Tablica pokazuje razvijenije komunikacijske vještine studenata u skupini PU-a u usporedbi s njihovim kolegama iz kontrolne skupine $(\mathrm{F}=5,279, \mathrm{P}=.023<.05)$. To znači da je strategija PU-a u ovoj studiji bila značajno učinkovitija u poboljšavanju komunikacijskih vještina studenata u PU skupini $(\mathrm{M}=3,30, \mathrm{SD}=.468)$ u usporedbi s kontrolnom skupinom $(\mathrm{M}=3,15$, $\mathrm{SD}=.453)$. Razlika aritmetičkih sredina u rezultatima predtesta emocija prema učenju (aritmetička sredina PU skupine $=2,75, \mathrm{SD}=.435$; aritmetička sredina kontrolne 
skupine $=2,95, \mathrm{SD}=.488)$ bila je značajna $(\mathrm{F}=19,915, \mathrm{p}=.000<.05)$. Na osnovi rezultata, analize tipova varijabli (zavisnih i nezavisnih) bile su provedene ANCOVAom (analizom kovarijance).

Rezultati u tablici 4 pokazuju statistički značajnu razliku aritmetičkih sredina emocija prema učenju, pri čemu PU grupa ima jače pozitivne emocije $(\mathrm{M}=3,75, \mathrm{SD}=.629)$ u usporedbi sa svojim kolegama iz kontrolne skupine $(\mathrm{M}=3,51, \mathrm{SD}=.748)$. Ipak, rezultat ANCOVA-e $(\mathrm{F}=5,552, \mathrm{p}=.020<.05)$ bio je značajan. To znači da je PU oblikovano u ovom istraživanju bilo značajno učinkovito u razvijanju pozitivnih emocija prema učenju u eksperimentalnoj skupini u usporedbi s kontrolnom skupinom. Vezano uz usporedbu zavisnih varijabli zasnovanoj na studijskoj grupi, provedena je MANOVA kako bi se utvrdilo postojanje značajnih razlika u aritmetičkim sredinama između tri čimbenika studijskih grupa na zavisne varijable komunikacije i emocija prema učenju. Kako prikazuje tablica 5, iako su rezultati deskriptivne statistike pokazali da su studenti iz područja zdravstva postigli višu aritmetičku sredinu $(\mathrm{M}=3,364, \mathrm{SD}=.503)$ od rezultata komunikacijskih vještina u usporedbi s onima u područjima inženjerstva ( $M$ $=3,303, \mathrm{SD}=.435)$ i znanosti $(\mathrm{M}=3,242, \mathrm{SD}=.472)$, rezultat MANOVA-e nije bio značajan $(\mathrm{F}=1,470, \mathrm{p}=.236>.05)$. Sukladno navedenome, studenti smjera zdravstva također su pokazali višu razinu pozitivnih emocija prema učenju $(\mathrm{M}=3,916, \mathrm{SD}=$ .621) u usporedbi sa studentima ostalih fakulteta, inženjerstva $(\mathrm{M}=3,708, \mathrm{SD}=.587)$ i znanosti $(\mathrm{M}=3,654, \mathrm{SD}=.666)(\mathrm{F}=.504, \mathrm{p}=.606>.05)$. Navedeno znači da je $\mathrm{PU}$, oblikovano za predstavljeno istraživanje, bilo značajno učinkovito u poboljšavanju rezultata aritmetičkih sredina u komunikacijskim vještinama studenata i promoviranju pozitivnih emocija u području zdravstva u usporedbi s ostalim područjima.

Tablica 3.

Tablica 4.

Tablica 5

\section{Rasprava}

Prvo pitanje odnosi se na utvrđivanje razlika između PU i kontrolnih skupina u komunikacijskim vještinama. Na osnovi dobivenih rezultata utvrđeno je postojanje značajne razlike između aritmetičkih sredina. Rezultati pokazuju kako je PU skupina imala više rezultate $u$ komunikacijskim vještinama od vršnjaka iz kontrolne skupine. Ovaj rezultat može se pripisati činjenici da studenti iz PU skupine dobivaju više podrške svoje okoline i većoj kompetitivnosti koja podiže njihovu razinu komunikacije. Rezultat se također može objasniti ugodom koju su osjećali u okružju predavaonice i njihovom osjećaju pripadanja. Dodatno, od studenata se zahtijevalo da rade u timovima kako bi riješili aktivnosti, što im je pomoglo da se nose sa zahtjevima i pritiscima nastave. Nadalje, PU se razlikuje od predavačke strategije, nudi različite strategije učenja, poput dinamike male skupine i učenja kroz stvarne životne situacije vezane uz žarišne teme, stoga može povećati komunikacijske vještine studenata. Nadalje, pristup PU-a potiče 
studente na razmjenu znanja i olakšava njihovu prilagodbu na nove stilove učenja. Tako im pomaže pri evaluaciji i rafiniranju njihova učenja dajući povratnu informaciju kroz međusobnu interakciju (Fung, 2013), što studentima pomaže u nadvladavanju komunikacijskih poteškoća. Štoviše, anketirani studenti bili su na drugom semestru studija i stoga se očekivalo da su imali vremena za poboljšanje komunikacijskih vještina. Ovaj je rezultat u skladu s prijašnjim nalazima Santona i ostalih (2010) koji podržavaju pozitivan utjecaj modula $\mathrm{PU}-\mathrm{a}$ na vještine studenata. $\mathrm{U}$ cjelini, prikazani rezultati pokazali su da je PU-e kao pristup poučavanja uspjelo poboljšati komunikacijske vještine studenata.

Drugim pitanjem nastojalo se utvrditi postojanje razlika u aritmetičkim sredinama između PU i kontrolnih skupina s obzirom na njihove emocije prema učenju. Deskriptivna analiza rezultata ukazala je na postojanje značajnih razlika, $\mathrm{u}$ čemu je PU skupina studenata postizala više rezultate u usporedbi s kontrolnom skupinom, u tome što su ispitanici iz prve skupine pokazali više razine pozitivnih emocija prema učenju. Ovaj bi rezultat mogao biti u vezi s činjenicom da je strategija PU-a primjerena za povećavanje pozitivnih emocija prema učenju. Ovaj se rezultat također može dovesti u vezi s činjenicom da je PU skupina studenata dobila više podrške okoline koja ih je motivirala i povećala njihovu razinu pozitivnih emocija prema učenju. Ipak, strategija PU-a promovirala je učenje i promijenila stav o učenju. Navedeno se također može dovesti u vezu s činjenicom da je PU skupina radila u timovima kako bi provela aktivnosti, što im je pomoglo pri upravljanju emocijama i odnosim $s$ vršnjacima. Naime, ti studenti imali su veće samopouzdanje, što je također moglo pridonijeti njihovim pozitivnim emocijama o učenju. PU metoda poučavanja također je omogućila grupnu interakciju s vršnjacima i okolinom u skupini PU-a. Njihova viša razina komunikacije također je mogla imati utjecaja na razvijenije pozitivne emocije prema učenju u usporedbi s vršnjacima iz kontrolne skupine. Ovaj je rezultat u skladu s onim iz istraživanja Hartman i suradnika (2014). U tom istraživanju autori podržavaju pozitivan utjecaj PU-a na percepcije studenata o njihovoj sposobnosti da koriste učenje fokusirano na emocije i upravljaju učenjem koje je usredotočeno na učenika i stvarnim rješavanjem problema. Takav tip rješavanja problema povećava sposobnosti studenata $\mathrm{u}$ upravljanju negativnim emocionalnim reakcijama povezanim s pritiskom i stresom. U međuvremenu, Lee i Kim (2005) ukazali su na snažan motivacijski učinak PU-a.

Naposljetku, trećim pitanjem nastojalo se utvrditi postojanje statistički značajnih razlika između istraživačkih varijabli na osnovi područja studija. Rezultati ove analize ukazali su da, iako su studenti smjera zdravstva postizali više rezultate u usporedbi $s$ dvije preostale skupine na komunikacijskoj ljestvici i emocijama vezanim uz učenje, razlike nisu bile značajne. To je možda zbog činjenice što sveučilište i njegovo osoblje zagovaraju jednakost u učenju za sve, raznolike studijske smjerove. Dodatno, osoblje koledža posebno je korisno u olakšavanju stjecanja znanja. U literaturi je potvrđeno da su emotivni status studenata i komunikacijske vještine pod utjecajem drugih čimbenika, poput osobnih i obitelji, stoga se ne može lako generalizirati. Ipak, razlike koje nisu 
statistički značajne u ovoj studiji mogu se objasniti činjenicom da su ispitanici iz Saudijske Arabije, iz kulturološkoga okružja u kojem obitelji skrbi o njima do kraja studija i činjenicom da od sveučilišta dobivaju mjesečnu potporu. Također, nije se očekivao bitan učinak obitelji ni socijalnih čimbenika, o čemu svjedoče prijašnja istraživanja koja izvještavaju o nepostojanju značajnoga utjecaja individualnih čimbenika poput obitelji, socijalnoga i ekonomskoga statusa na postignuća studenata na saudijskim sveučilištima (Al-Shawwa i sur., 2015). Nadalje, studenti različitih studijskih grupa bili su uspješni u razumijevanju nastavnih sadržaja i bili prisutni na jednakom broju sati praktične nastave koja je mogla doprinijeti njihovim pozitivnim stavovima prema učenju. Studenti tri smjera možda su uživali radeći zajedno koristeći strategiju PU-a koja im je omogućila učinkovitu raspravu o problemima i poboljšale njihovu sposobnost stvaranja i formuliranja vlastitih mišljenja. Navedeno je sukladno nalazima istraživanja (McLean, Wyk, Futre i Higgins-Opitz, 2006; Alajmi, 2014). Razlog zbog čega rezultat nije statistički značajan može biti i u činjenici što je motivacija sveučilišnih studenata manje osjetljiva na kontekstualne čimbenike istraživanja. U odnosu na ovaj rezultat, Wigfield, Battel i Keller (2002) navode kako kumulativno iskustvo diskretnih emocija u okružju predavaonice očekivano vodi stabilnosti emocionalne percepcije u vezi sa specifičnim domenama i životnim učenjem. Rezultat se također može opravdati činjenicom da su studenti dobili više podrške i imali zdravu razinu kompetitivnosti, bez obzira na studijsku grupu. Rezultat nije sukladan s rezultatima Parpala, LindblomYlanne i Rytkonen (2006) koji tvrde da različite discipline imaju različite pristupe učenju i poučavanju, prakse i iskustva. Rezultati aritmetičkih sredina studenata podržavaju druga prošla istraživanja, poput onog Goetz, Frenzel, Ludtke i Hall (2010) koji navode da studenti doživljavaju različite emotivne razine u različitim područjima. Takve razlike mogu se dogoditi zbog sastava, dinamike, kompeticije i vršnjačke podrške u učionici (Goetz, Ludtke, Nett, Keller i Lipnevich, 2013).

\section{Zaključak}

Ovo istraživanje pridonijelo je području obrazovanja i potaknulo buduća istraživanja da ispitaju predmetnu građu koristeći i kvantitativne i kvalitativne pristupe kako bi obogatila informacije o studentskoj percepciji vlastitoga studiranja. Podatci dobiveni putem samoizvještaja studenata u ovoj studiji govore o njihovoj percepciji vlastitoga studiranja. Štoviše, podatci u ovoj studiji dobiveni su od studenata koji žive u istočnoj regiji Saudijske Arabije pa individualni čimbenici nisu testirani zbog financijske potpore sveučilišta studentima i promocije socijalnih vještina u aktivnostima. Stoga bi buduća istraživanja mogla uključiti druga sveučilišta iz različitih kultura i zemalja kako bi se došlo do drugačijih rezultata. Neka prijašnja istraživanja ne pokazuju statistički značajnu razliku u postignućima saudijskih studenata povezanu s utjecajem ekonomskoga statusa. Rezultati ove studije mogu se objasniti činjenicom da je istraživanje prekratko trajalo. S obzirom na navedeno, buduća bi istraživanja mogla koristiti longitudinalni pristup kako bi obogatilo tumačenje odnosa proučavanih varijabli. Većina ispitanika 
bili su dodiplomski studenti istoga spola, stoga buduća istraživanja mogu uključiti druge studente na različitim razinama studija (npr. poslijediplomskoj) i razne semestre, kako bi pružila više informacija o predmetnoj građi. Budući radovi također mogu provesti usporedbe različitih disciplina utemeljene na varijablama ovoga istraživanja i drugima. Konačno, budući autori mogu istražiti odnos između varijabli i stvarnih rezultata studenata koji se odražavaju kroz ocjene studenata. Nezavisna varijabla ispitana u ovom istraživanju je PU, a zavisne varijable su komunikacijske vještine i emocije prema učenju u dvije skupine studenata - dodiplomski studenti smjera zdravstva, inženjerstva i znanosti podijeljeni u PU i kontrolne grupe. Kroz ispitivanje varijabli, ovo istraživanje doprinosi literaturi na četiri načina: prvo, utvrđivanjem učinkovitosti modula PU-a na komunikacijske vještine i emocije prema učenju među studentima koji su činili uzorak i, drugo, razvojem strategije PU-a u kontekstu Saudijske Arabije. Treći doprinos odnosi se na određivanje učinka strategije PU-a na emocije prema učenju, čime se dosadašnja literatura nije puno bavila. Četvrti doprinos odnosi se na učinak PU-a na komunikacijske vještine i emocije prema učenju studenata, $s$ usporedbom tih učinaka između ispitanika s tri fakulteta na kojima studiraju. Rezultati doprinose korpusu slične literature kroz nove informacije i znanje, budući da su se prijašnja istraživanja koncentrirala samo na neke varijable i pružala opće rasprave o temama komunikacije u raznim okruženjima. Rezultati istraživanja također upućuju na ulogu strategije PU-a na dizanje razine komunikacije studenata i obogaćivanje njihovih pozitivnih stavova prema okolini učenja. Očekuje se kako bi razvoj nastavnoga procesa prema strategiji PU-a, i formalno i neformalno olakšao socijalne odnose studenata i njihovo upravljanje emocijama, što posljedično može povećati njihov uspjeh u učenju. 